\title{
Identifikasi Ken Dedes Dalam Arca Perwujudan Sebagai Dewi Prajnaparamita : Tinjauan Filsafat Religi dan Ikonografi
}

\section{Suwardono}

Keywords: folklore, east java, goddess, religion, beliefs, iconography

\section{How to Cite:}

Suwardono, nfn. (2007). Identifikasi Ken Dedes Dalam Arca Perwujudan Sebagai Dewi Prajnaparamita : Tinjauan Filsafat Religi dan Ikonografi. Berkala Arkeologi, 27(1), 98-117. https://doi.org/10.30883/jba.v27i1.945

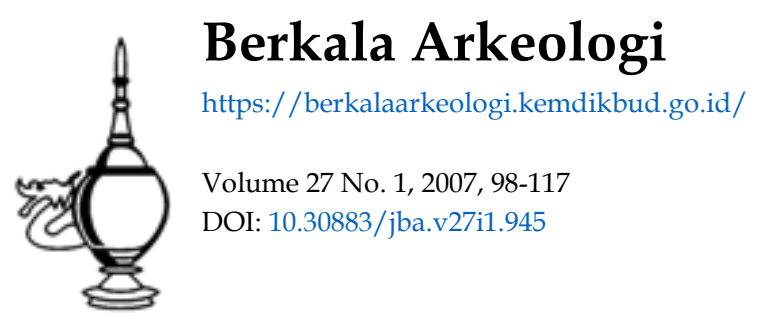

\section{(i) (2)}

This work is licensed under a Creative Commons Attribution-NonCommercial-ShareAlike $\underline{4.0 \text { International License. }}$ 


\title{
IDENTIFIKASI KEN DÊDÊS \\ DALAM ARCA PERWUJUDAN \\ SEBAGAI DEWI PRAJÑAPARAMITA : \\ Tinjauan Filsafat Religi dan Ikonografi
}

\author{
Suwardono \\ (Dinas Pendidikan Kota Malang)
}

\section{Latar Belakang}

Dikalangan masyarakat Malang dan sekitarnya, sosok Ken Dedes (baca: Dêdês) sebagai seorang putri Jawa kuno yang dipandang sangat cantik jelita sudah bukan barang baru lagi. Anggapan ini mencuat dipermukaan pada dekade awal abad 19, ketika orang Belanda menemukan reruntuhan di komplek percandian Singosari. Salah satu temuan dari reruntuhan itu adalah sebuah arca batu yang sangat indah yang ditemukan di candi Wayang atau candi $E$ (menurut laporan-laporan Belanda), sebuah arca dari pantheon agama Budha Mahayana yaitu Dewi Prajñaparamita. Ketika arca tersebut untuk sementara berada di tempat residen di Malang, Monnerau, Residen Malang waktu itu menghubungkan arca Dewi Prajñaparamita tersebut dengan cerita penduduk tentang Ken Dedes (Blom, 1976). Dari sinilah dugaan awal timbulnya anggapan bahwa arca Dewi Prajñaparamita adalah portret dari Ken Dedes.

Jauh dikemudian hari di abad 20 , kenyataan anggapan ini dibuktikan dengan sering diadakannya suatu kontes yang disebut 'Pemilihan Putri Ken Dedes' hampir setiap tahunnya. Gaung figur kecantikan itu tidak hanya stagnan di kawasan lereng timur gunung Kawi, bahkan masyarakat luas (baca: Indonesia) terbawa arus ikut mengakui kecantikan dan kejelitaannya.Usaha pengenalan figur tidak hanya sampai disitu, pihak pemerintah daerah kota Malang memberanikan diri untuk membuat sebuah arca tiruan Dewi Prajñaparamitha yang sangat besar yang ditempatkan di tengah taman kota di perbatasan antara Kelurahan Polowijen dan Arjosari. sebuah wilayah kelurahan yang berada diujung utara kota Malang. Penempatan arca tiruan tersebut tidak tanpa alasan, mengingat Ken Dedes disebutkan berasal dari Panawijen (sekarang Polowijen). 
Sekitar tahun 1999 Himpunan Ahli Rias Pengantin Indonesia (HARPI) Melati Malang, meluncurkan buku pedoman tata rias pengantin yang diberi judul 'Malang Keprabon'. Dalam pengemasan busana dan atributnya ternyata pengantin putri berorientasi pada sosok putri Ken Dedes sebagai Dewi Prajñaparamita. Sedangkan pengantin pria berorientasi pada sosok Ken Angrok (tidak diketahui diambil dari figur arca siapa). Sungguh pun ternyata tampilannya masih jauh dari makna sosok yang dimaksudkan. Ditunjang pula dengan bentuk- bentuk ornamentasi lain yang khas yang diambil dari ragam hias percandian yang terdapat di sekitar Malang (terutama Badut, Kidal, dan Jago).

Sementara itu di lapangan, banyak masyarakat (baik dari Malang maupun dari luar Malang), yang mempercayai bahwa situs patirthan 'Watu Gede' yang terletak di sebelah timur setasiun kereta api, Dukuh Sanan, Desa Watugede, Kecamatan Singosari, merupakan bekas sendang atau taman sari sebagai tempat mandi Ken Dedes. Kepercayaan ini membawa kepada sebagian orang, terutama para wanita untuk memburu berkah terhadap air sendang tersebut. Mereka beranggapan bahwa mandi di sendang 'Watu Gede' akan awet muda dan bersinar seperti Ken Dedes. Di lain tempat, yaitu di situs 'Sumur Windu' atau juga disebut 'Petilasan Ken Dedes' yang berada di kawasan pekuburan umum Kelurahan Polowijen, Kecamatan Blimbing, Kota Malang. Masyarakat sekitar mempercayai bahwa tempat petilasan tersebut adalah sebuah tempat 'Moksa' bagi Ken Dedes. Di saatsaat tertentu banyak orang datang ke tempat tersebut guna keperluan yang bermacam-macam. Kasusnya sama seperti yang dikatakan orang sebagai 'petilasan Joyoboyo' di Mamenang Kediri.

Mencermati semua fakta di atas, begitu kuatnya pengaruh figur Ken Dedes bagi masyarakat Malang (Jawa) terutama kaum wanitanya. Seakan ia adalah lambang kecantikan, kejelitaan, serta kelembutan seorang wanita Jawa. Dari sosok wanita Jawa kuno ini mereka banyak mengambil suri teladan baik fisik maupun psikisnya.

\section{Masalah dan Tujuan}

Banyaknya anggapan yang mengatakan bahwa sosok Ken Dedes merupakan seorang wanita Jawa kuno yang memiliki kecantikan serta 
kepribadian yang lembut yang dipersonifikasikan sebagai Dewi Prajñaparamita, maka permasalahan yang muncul di sini adalah dapatkah figur Ken Dedes diidentifikasikan sebagai Dewi Prajñaparamita?

Makalah ini bertujuan untuk mengetahui syarat-syarat apa yang dimiliki oleh figur Ken Dedes sehingga ia diwujudkan sebagai Dewi Prajñaparamita.

\section{Metode Penelitian}

Guna memecahkan permasalahan tersebut di atas digunakan metode kajian pustaka dengan jenis penelitian historis. Dimana dalam penelitian historis pemecahan masalahnya menggunakan data dari masa lampau, serta fokus ditujukan untuk memahami kejadian atau suatu keadaan yang berlangsung pada masa lampau (Nawawi, 1985:78-82). Pendekatan ini dipakai untuk mengetahui isi dari data tekstual yang dipakai sebagai sumber utama dalam meneliti identifikasi tokoh Ken Dedes sebagai Dewi Prajñaparamita. Tahapan-tahapan yang dilakukan dalam metode historis adalah:

1) Heuristik; yaitu kegiatan untuk mencari dan mengumpulkan sumbersumber sejarah, yaitu jejak sejarah sebagai peristiwa untuk disusun dalam bentuk sejarah sebagai kisah

2) Kritik; yaitu kegiatan untuk meneliti apakah sumber itu asli, baik bentuk maupun isinya. Kegiatan ini terbagi menjadi kritik ekstern dan kritik intern dalam melakukan pemilihan dan penentuan terhadap sumber sejarah yang diperlukan

3) Interpretasi; yaitu menetapkan makna yang saling berhubungan dari fakta-fakta yang diperoleh, setelah fakta tersebut dapat dibuktikan kebenarannya

4) Historiografi; yaitu penyampaian sintesa yang diperoleh dalam bentuk suatu kisah sejarah (Notosusanto,1978:35-36). yang berlangsung pada masa lampau (Nawawi, 1985:78-82).

\section{Evaluasi Data}

\section{a. Identifikasi Tokoh Ken Dedes}

Riwayat hidup Ken Dedes hanya diketahui melalui sebuah kitab Jawa pertengahan yaitu Pararaton yang selesai ditulis di Selapenek pada tahun saka 1535 pada hari Sabtu pahing wuku Warigadyan tanggal 2 kresnapaksa (Padmapuspita, 1966:91) atau ekuivalen dengan tanggal 30 Mei $1614 \mathrm{M}$. 
Sumber lainnya adalah cerita tradisi berupa cerita tutur masyarakat Malang terutama daerah Polowijen.

Kitab Pararaton menceritakan tokoh Ken Dedes sejak berada di Panawijen sebagai anak tunggal seorang pendeta Budha aliran Mahayana bernama Mpu Purwa, yang diperkirakan hidup pada antara kwartal terakhir abad XII sampai kwartal ke dua abad ke XIII M. Kemudian menjadi istri dari seorang akuwu di Tumapel, dan hingga pada akhirnya menjadi parameswari dari pendiri kerajaan Singasari, yaitu Sri Ranggah Rajasa Amurwabhumi. Pemberitaan Pararaton tentang Ken Dedes sebagai seorang anak pendeta Budha Mahayana di Panawijen adalah sebagai berikut:

Dadi hana bhujangga boddhasthâpaka ring Panawijen, lumaku Mahâyâna, atapa ring setraning wong Panawijen, apu'pata sira mpu Pûru'a. Sira ta anakanak stri tunggal, duk derengira Mahâyâna; atyanta ring listu-hayuning putrinira, aran ken Dêdês. Sira ta kawêrta yen hayu, tan hana amadani rupanira yen sawetaning Kawi kasub têkeng Tumapêl. Karungu denira Tunggul amêtung, tumuli sira Tunggul amêtung datêng ing Panawijen, añjujug maring dukuhira mpu Pûrwa, kapanggih sira ken Dêdês, atyanta garjitanira Tunggul amêtung tumon ing rara hayu. Katuju sira mpu Pûrwa tan hana ring patapanira, samangka ta ken Dêdês sinahasa pinalayokên denira Tunggul amêtung. Saulihira sira mpu Pûrwa saking paran tan katêmu siranakira, sampun pinalayokên denira sang akuwu ring Tumapêl, tan wruh ring kalinganira, ya ta sira mpu Pûrwa anibakên samaya tan rahayu, lingira: "Lah kang amalayokên anakingsun mogha tan tutuga pamuktine matia binahud angêris; mangkana wong Panawijen asata pangangsone, mogha tan mêtua bañune bejine iki, dosane nora awarah iringsun yen anakingsun den-walating wong". Mangkana lingira mpu Pûrwa. "Kalawan ta anakingsun marajakên karma amamadangi, anghing sotmami ring anakmami 'mogha anêmwa rahayu den agung bhâgyane'. Mangkana sotira Mahâyâna ring Panawijen.

Satêkanira ken Dêdês ring Tumapêl rinowang sapaturon denira Tunggul amêtung, tan sipi sihira Tunggul amêtung, wahu ngidam sira ken Dêdês, dadi sira Tunggul amêtung akasukan, acangkrama somahan maring taman Boboji, sira ken Dêdês anunggang gilingan. 
Satêkanira ring taman sira ken Dêdês tumurun saking padati, katuwon pagawening widhi, kengis wêtisira, kongkab têkeng rahasyanira, nêhêr katon murub denira ken Angrok, kawêngan sira tuminghal, pituwi dening hayunira anulus, tan hanâmadani ring listuhayunira, kasmaran sira ken Angrok tan wruh ring tingkahira.

Saulihira Tunggul amêtung saking pacangkraman, sira ken Angrok awarah ing sira danghyang Lohgawe, lingira:"Bapa danghyang, hana wong istri murub rahasyane, punana lak aòaning stri lamun mangkana, yen hala rika yen ayu rika lak'aòanipun". Sumahur sira danghyang:"Sapa iku kaki". Lingira ken Angrok:"Wontên, bapa, wong wadon katinghalan rahasyanipun deningsun". Lingira danghyang Lohgawe:"Yen hana stri mangkana, kaki, iku stri nâriçwari arane, adimukyaning istri iku, kaki, yadyan wong papa angalapa ring wong wadon iku, dadi ratu añakrawarti" (Padmapuspita, 1966:17-18).

Sementara itu cerita rakyat dalam bentuk cerita tutur yang sampai sekarang dapat digali dari penduduk Polowijen adalah sebagai berikut:

"Diceritakan bahwa jaman dahulu di Polowijen ada seorang gadis yang berparas cantik jelita, bernama ndedes (Ken Dedes). la akan dijodohkan dengan seorang laki-laki dari Dinoyo, bernama Joko Lulo. Tetapi Ken Dedes tidak menuruti begitu saja kehendak orang tuanya. Dia mau menikah dengan meminta syarat yang harus dipenuhi sebelum pernikahan, yaitu supaya dibuatkan sumur yang dalam sekali. Kedua orang tuanya tidak keberatan dan mengabulkan, yang kemudian menyuruh orang untuk membuat sumur yang sangat dalam (versi yang diceritakan oleh sebagian penduduk yang lain menyebutkan bahwa Ken Dedes meminta syarat kepada Joko Lulo untuk dibuatkan sumur yang sangat dalam). Saat pesta pernikahan tiba, maka semua persiapan telah diatur secara meriah, dan kedua pengantin akan dipertemukan dengan diiringi musik dari seperangkat gamelan. Dari pihak Joko Lulo meminta bahwa acara temu pengantin tersebut harus tengah malam, tidak boleh melewati waktu orangorang perempuan membunyikan tempat nasi (bhs. Jawa: tompo), karena hal itu menandakan bahwa hari mulai terang/pagi. 
Begitulah ketika pengantin hendak dipertemukan, tidak disangka terdengar bunyi tempat nasi dipukul oleh para wanita, sedangkan di sebelah timur tampak langit kemerah-merahan tanda fajar mulai menyingsing, ayam berkokok bersahut-sahutan. Saat itulah tampak wajah Joko Lulo yang buruk. Hal itu diketahui oleh Ken Dedes yang pada awalnya memang merasa curiga dan tidak menyukainya. Suasana menjadi kacau, para pengiring gaduh dan semua alat gamelan yang dibawa berhamburan. Joko Lulo kemudian mengumpat para wanita pemukul tempat nasi, 'Semoga kelak semua anak perawan di Polowijen tidak akan kawin atau dapat jodoh sebelum payudaranya turun ke bawah seperti orang yang sudah mempunyai anak'. Pada akhirnya di kedua belah pihak antara orang tua Joko Lulo dan orang tua Ken Dedes sepakat untuk tidak lagi menjodohkan anaknya dari desa mereka masing-masing.

Dalam situasi yang serba kacau tersebut Ken Dedes akhirnya menghilang dengan menceburkan dirinya ke dalam sumur yang telah dibuat sebagai syarat pernikahan. Mengetahui Ken Dedes masuk ke dalam sumur, tanpa berpikir panjang Joko Lulo mengikuti masuk. Sedangkan alat-alat gamelan yang berserakan berubah menjadi batu, yang sekarang sisanya tinggal satu dan oleh penduduk disebut batu kenong. Sumur dimana Ken Dedes dan Joko Lulo menceburkan diri, sekarang menjadi sebuah tempat yang oleh penduduk Polowijen disebut 'Sumur Windu' atau 'punden Ken Dedes'.

Dengan hilangnya Ken Dedes, dibuatlah sayembara, barang siapa dapat menemukan Ken Dedes kembali, maka ia akan dikawinkan dengan gadis tersebut. Alkisah adalah seorang yang sangat sakti bernama 'Maling Aguno'. Dalam mencari Ken Dedes yang masuk ke dalam sumur, ia membuat terowongan yang jauh sekali. la mencari kesana kemari namun tidak mendapatkan hasil. Akhirnya gagallah pencarian tersebut. Dan sisa-sisa terowongan itu sekarang masih ada, yaitu yang ditemukan orang ketika menggali tanah untuk pembuatan sumur. Sementara itu dengan tidak ditemukannya Ken Dedes, orang tua dan penduduk desa Panawijen menjadi putus asa dan pasrah. Di kemudian hari barulah diketahui bahwa Ken Dedes dalam pelariannya muncul di Singosari (Tumapel). la diketahui telah menjadi istri dari akuwu Tumapel yaitu Tunggul Ametung"(Suwardono, 2005:48-49). 
(Padmapuspita, 1966:91) atau ekuivalen dengan tanggal 30 Mei $1614 \mathrm{M}$. b. Identifikasi Arca Prajñaparamita

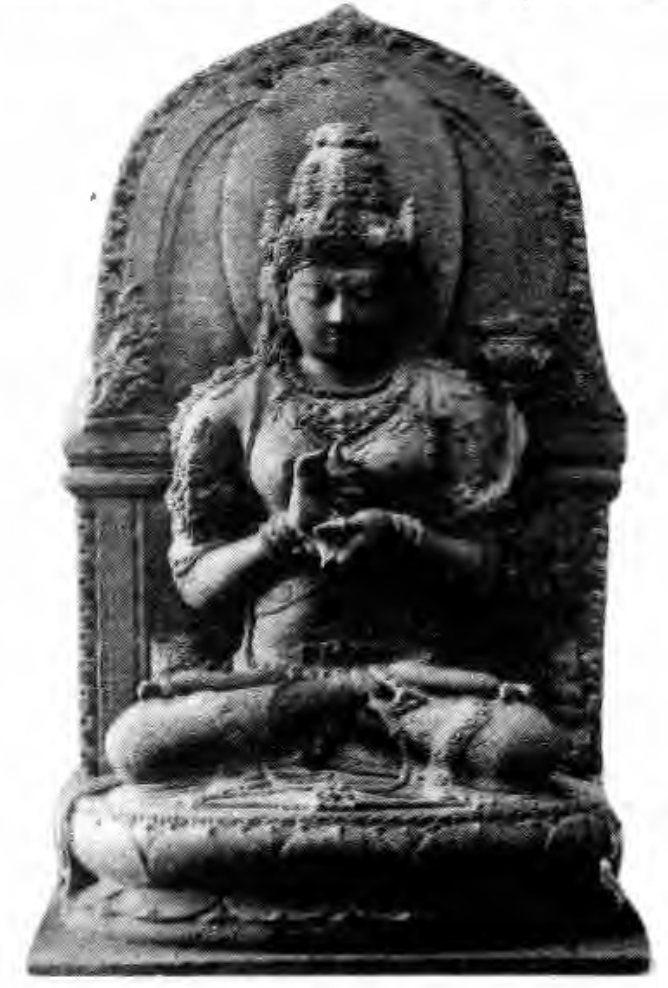

Arca Prajnaparamita dari percandian Singosari

Laporan Belanda menyebutkan bahwa arca Prajñaparamita ditemukan di antara reruntuhan selatan komplek percandian Singosari (dengan candi Singosari berjarak $\pm 500 \mathrm{~m}$ arah selatan). Blom dengan pengumpulan data hasil laporan pendahulunya sejak reruntuhan Singosari diberitakan oleh Nicolas Engelhard tahun 1803, dapat memberikan kesimpulan bahwa arca tersebut ditemukan di salah satu candi, yaitu candi $E$ menurut sketsa para peneliti Belanda, candi Wayang menurut H.N.

Sieburgh, atau candi Putri menurut penduduk setempat (Blom, 1976). Dimana sisa-sisa situs tersebut berada di Jalan Bungkuk Gg.II Kelurahan Pagentan, Kecamatan Singosari. Tempat itu sekarang hanya tinggal tanah tegalan dengan ukuran $\pm 12 \times 25$ m yang kanan-kirinya sudah dipadati oleh bangunan rumah penduduk.

Arca dari batu andesit yang masih utuh dan dikategorikan sangat indah buatannya itu kemudian dibawa ke tempat Residen Malang, yang pada waktu itu residen dijabat oleh Monnerau. Penemuan arca yang cukup menggemparkan itu di belakang hari membawa buntut yang sangat panjang dalam penafsirannya. Oleh Monnerau yang diduga ia termakan oleh ceritacerita penduduk Malang, arca tersebut dihubungkan dengan sebuah arca bermata satu yang kasar buatannya, yang oleh penduduk disebut Joko Lulo (Blom, 1976:84). Akhirnya arca dari candi Wayang atau Putri tersebut mendapatkan namanya yaitu Putri Dedes atau Ken Dedes. Sejak saat itulah hingga sekarang arca dari pantheon agama Budha Mahayana 
Arca Prajñaparamita berukuran 1.26 m (Bernet Kempers, 1959:75), duduk dalam sikap padmasana atau vajrasana (kedua kaki disilangkan dengan kedua telapak kaki menghadap ke atas, telapak kaki kanan berada di atas paha kiri, telapak kaki kiri berada di atas paha kanan), di atas bantalan bunga teratai merah yang memiliki dua kelopak bunga yang menghadap ke atas dan ke bawah (padmasana ganda). Bantalan padma berada di atas asana segi empat dengan hiasan geometris. Bagian belakang arca terdapat sandaran yang atasnya membentuk kurawal runcing dengan hiasan lidah api tumpul yang mengelilingi pinggirnya. Sandaran yang sekaligus bermakna sebagai prabhavali ini menopang keseluruhan badan arca dan menyatu dengan tempat duduk. Di dalam prabhavali masih terdapat bulatan lonjong tepat di belakang kepala, yaitu çirascakra atau prabhamandala yang merupakan lambang kedewaan dari tokoh yang digambarkan, atau pula dapat dikatakan sebagai lambang cahaya kesucian.

Mahkota yang dikenakannya berbentuk kiritamakuta yang motifnya tidak didapat pada arca-arca lain. Mahkota ini pada sisi-sisinya dikelilingi oleh empat simbar besar dalam posisi pada pusat penjuru mata angin, sedang empat simbar yang lebih kecil lagi berada pada posisi penjuru mata angin lainnya. Posisi simbar-simbar pada sisi mahkota mengingatkan kita kepada konsep Meru yang terdiri dari puncak tertinggi yang dikelilingi oleh empat puncak yang lebih rendah.

Roman mukanya tenang dengan pandangan mata terpusat pada ujung hidung. Model face semacam itu jika dibandingkan dengan arca Siwa dari candi Kidal yang merupakan arca perwujudan Anusanatha/Anusapati, kini tersimpan di Amsterdam (Bernet Kempers, 1959:74) banyak memiliki persamaan. Dimana antara kedua arca ditinjau dari segi ikonografis, bentuk dan gaya pahataninya menunjukkan gaya kesenian Singasari yang berasal dari abad ke-13 (Stutteirheim, 1939:97). Sehingga muncul dugaan bahwa kedua arca tersebut bersumber pada panduan çilpa yang sama.

Pada keningnya terdapat bulatan berbentuk bunga teratai merah kecil sebagai Urna. Atribut perhiasan yang dipakai sangat raya (samboghakaya), sehingga kesan telanjang pada badan bagian atas yang memang tidak berkain tampak tertutupi oleh perhiasan yang dikenakannya. Memakai anting 
(kundala) dari bunga padma. Dibahunya terdapat hiasan lempeng emas yang tipis yang dihias dengan manik-manik. Hiasan tersebut terjuntai dari sisi mahkota di belakang telinga. Pada bagian ini juga terikat semacam untaian kalung yang panjang yang terjuntai ke. bawah hingga lutut. $\mathrm{Di}$ lehernya tampak tiga guratan sebagai tanda kemakmuran dan kelebihan. Leher tersebut juga dihias dengan kalung (hara) yang ganda pula. Satu kalung berbentuk untaian manik-manik, sedang kalung di bawahnya berbentuk lempengan emas yang dihias dengan permata yang bermotif. Sementara tali kasta yang sangat istimewa bentuknya melilit badannya dari pundak kiri melintang ke bagian bawah lambung kanan. Keistimewaan tali kasta (upavita) ini adalah, tepat di depan lambung kanan merupakan lempengan emas yang diberi hiasan padma.

Pada kedua lengannya terdapat kelat bahu (keyura) ganda. Memakai perhiasan gelang tangan (kankana) yang masing-masingnya sebanyak tiga buah. Sedang pada jari-jari tangannya, yaitu ibu jari, telunjuk, dan jari tengah mengenakan cincin (angulika). Kedua telapak tangan membentuk sikap 'Dharmacakramudra' yang jari-jarinya dipola dalam gaya tari. Lengan tangan kiri mengapit tangkai bunga teratai merah (padma) yang menjalar dari umbi (suatu ciri khas dari kesenian Singasari) yang terdapat di samping pinggangnya. Tangkai itu ke atas tepat di sisi bahu kiri dengan kelopak bunga yang mekar, di atas kelopak bunga terdapat pustaka (kitab).

Bagian bawah mengenakan kain yang bermotif 'Jlamprang', suatu motif lingkaran yang saling bersinggungan satu dengan lainnya. Bagian dalam lingkarannya bermotif senjata cakra yang diisi oleh motif steliran yang rumit, sedang bagian sisi luar bulatan diisi dengan motif roset yang mengarah ke motif cakra pula. Mengenakan ikat pinggang (katibandha) yang dihias dengan ikatan untaian-untaian manik-manik yang terjuntai ke bawah. Sedangkan di bagian pinggul sisi belakang terdapat simpul kain yang berhias motif teratai yang rumit pula. Kedua kaki memakai gelang/binggel (nupura). Seperti halnya ibu jari tangan, ibu jari kaki juga memakai cincin (angulika). 


\section{Pembahasan}

Memperhatikan bukti-bukti di atas, sebenarnya tidak sesederhana itu untuk memberikan suatu pernyataan bahwa arca Prajñaparamita yang dimaksudkan adalah portret dari Ken Dedes. Sementara data-data di lapangan yang mendukung ke arah sana sangat terbatas. Di sisi lain dokumen tertulis berupa prasasti maupun naskah yang menunjuk bahwa Ken Dedes diarcakan sebagai arca Prajñaparamita tidak ada.

Tentang arca Prajñaparamita sendiri disinggung dalam Negarakertagama pupuh LXIX:1. Disana disebutkan adanya sebuah tempat bernama Prajñaparamitapuri, yaitu sebuah candi makam yang dibangun dan diperuntukkan bagi Sri Rajapatni. Sedangkan arcanya sekaligus diberkahi oleh sang pendeta Jnanawidhi. Sri Rajapatni adalah sebutan bagi putri Gayatri yang merupakan istri keempat dari R. Wijaya atau Kertarajasa. Pupuh LYXXIV:1 menegaskan bahwa Prajñaparamitapuri itu dibangun di Bayalangu (Bayalangu adalah sebuah daerah di Tulungagung. Di tempat tersebut memang terdapat sisa-sisa bangunan agama Budha Mahayana).

Apabila konsisten kepada pemberitaan Negarakertagama, maka dapat ditarik kesimpulan bahwa yang diarcakan sebagai dewi Prajñaparamita dengan dibuatkan candi makamnya adalah Gayatri, putri bungsu raja Kertanegara. Menanggapi hal tersebut, Slametmulyana lebih jauh memberikan tafsiran bahwa arca Prajñaparamita yang ditemukan di Singosari itu diduga adalah arca perwujudan dari Sri Rajapatni atau Gayatri yang diletakkan di candi Prajñaparamitapuri di Bayalangu. Alasan Slametmulyana menempatkan Gayatri sebagai pemegang status perwujudan Prajñaparamita karena menurutnya berdasar prasasti Penanggungan 1296 dan prasasti Kertarajasa 1305, Gayatri dipuja-puja kecantikannya, oleh karena itu paling dikasihi oleh R. Wijaya atau Kertarjasa Jayawardhana. (Slametmulyana, 1979:233).

Anggapan yang dilontarkan oleh Slametmulyana berdasarkan naskah Negarakertagama, prasasti Penanggungan, dan prasasti Kertarajasa memang sangat beralasan. Tetapi penentuan lokasi temuan arca Prajñaparamita (Ken Dedes) jelas-jelas adalah di candi putri atau candi Wayang Singosari, bukan di Bayalangu. Apakah dapat ditafsirkankan bahwa 
arca Prajñaparamita itu dibuat di Singosari yang kemudian akan dibawa ke Bayalangu? Atau apakah sebaran arca Prajñapramita di lapangan memang lebih dari satu?

Apabila dicermati dengan seksama bahwa arca Prajñaparamita pada jaman Singasari-Majapahit tidak menutup kemungkinan lebih dari satu. Sampai saat ini secara riil terdapat tiga arca Prajñaparamita yang dijumpai di lapangan. Pertama adalah arca Prajñaparamita (Ken Dedes) yang sudah banyak dikenal orang karena keindahannya. Arca tersebut sekarang disimpan di Museum Nasional, Jakarta. Arca Prajñaparamita kedua, berada di halaman candi Singosari dengan ukuran yang cukup besar. Sayangnya arca ini sudah tidak berkepala lagi, dan hiasannya tidak semewah arca Prajñaparamita (Ken Dedes). Kekhususan yang menandai arca Prajñaparamita di halaman candi Singosari dengan arca Prajñaparamita (Ken Dedes) adalah adanya hiasan Vjalaka (hiasan gajah dan singa pada kanan kiri sandarannya). Arca Prajñaparamita ketiga, terdapat pada sisasisa candi Gayatri atau candi Gilang di Desa Bayalangu, Kecamatan Bayalangu, Tulungagung. Di lokasi ini ditemukan beberapa arca yang salah satunya adalah arca Prajñaparamita yang sudah rusak.

Jika kembali kepada analisa Slametmulyana, maka dapat diduga bahwa ditinjau dari tempat temuannya, arca Prajñaparamita yang dimaksud di dalam naskah Negarakertagama adalah arca Prajñaparamita yang sekarang berada di candi Gayatri atau candi Gilang di Bayalangu itu. Di dalam Negarakertagama bangunan sucinya disebut Prajñaparamitapuri.

Dengan menetapkan anggapan bahwa arca Prajñaparamita di Bayalangu adalah perwujudan dari putri Gayatri. Sekarang tinggal menentukan, arca Prajñaparamita yang ditemukan di reruntuhan candi Putri atau candi Wayang di Singosari tersebut arca perwujudan siapa? Dapatkah arca perwujudan itu diidentifikasikan sebagai perwujudan Ken Dedes? Sementara di dalam Dinasti Rajasa (Singasari-Majapahit) banyak bangsawan wanitanya yang dapat dikatakan memiliki kelebihan disamping Ken Dedes sendiri. Seperti Nararya Waning Hyun (Jayawardhani istri dari Wisnuwardhana), keempat istri R. Wijaya (Tribhuwaneswari, Narendraduhita, Prajñaparamita, dan Gayatri), ratu Tribhuwanottunggadewi, dan ratu Suhita. $k$ wanita yang dapat dikatakan mempunyai kelebihan. 
Sosok Ken Dedes sendiri secara legendaris tertanam di hati rakyat dan selalu dihubungkan dengan lambang keluwesan, kecantikan, dan tabiat lemah lembut dari seorang wanita Jawa khususnya Jawa Timur. Memang demikianlah keberadaan Ken Dedes sendiri sebagai figur seorang wanita Jawa kuno yang hidup sekitar akhir abad XII M. sampai awal abad XIII M. Kecantikan dan kelembutannya diberitakan di dalam kitab Pararaton bahwa kecantikan dan keluwesannya sungguh sangat sempurna, oleh karenanya tidak ada yang menyamai di kawasan timur Gunung Kawi.

Kitab Pararaton hanya memberitakan kecantikan yang berlebihan itu. Sementara dalam tambahan pemberitaannya Pararaton menyatakan bahwa Ken Dedes disebut sebagai seorang 'Nareswari'. Istilah Nareswari dalam kamus Jawa kuno Zoetmulder dapat diartikan sebagai 'yang paling unggul di antara wanita; wanita seperti ratu' (Zoetmulder, 2004:693). Berkenaan dengan sebutan Ken Dedes sebagai seorang Nareswari, yaitu ketika ia dengan suaminya Tunggul Ametung sedang bercengkerama di taman Boboji, yang kebetulan pada waktu itu Ken Angrok bertugas sebagai prajurit pengawal taman. Pada saat itulah nampak rahasia kewanitaan Ken Dedes oleh Ken Angrok. Cahaya berkilau dari rahasia kewanitaan Ken Dedes merupakan isyarat dalam Pararaton bahwa Ken Dedes bukanlah sekedar seorang wanita putri pendeta Budha Mahayana. Orang Jawa biasa menyebut hal semacam itu adalah 'Pulung', yaitu semacam aura yang melingkupi jiwa dan jasmani seseorang sebagai manusia pilihan.

Pemberitaan Pararaton mengenai Ken Dedes dilingkupi pola pemikiran atau kepercayaan magis mistis. Memang demikianlah kadar penulisan Pararaton sesuai dengan jamannya. Menurut alam filsafat ajaran Hindu Budha, kedudukan seorang raja dan permaisuri di kerajaan merupakan gambaran mikro dari alam semesta. Raja adalah titisan dewa di dunia (Geldern dalam Noer, 1982:16). Oleh karena itu wajar apabila alam kedewaan sangat kuat melingkupi pola pikir filsafat masyarakatnya.

Penekanan yang berulang-ulang tentang kegaiban yang dialami oleh Ken Dedes merupakan sebuah image sastrawan dalam karyanya guna menunjukkan bahwa Ken Dedes adalah wanita cikal-bakal atau sumber benih dari raja-raja Singasari dan Majapahit (masalah ini sering dikemukakan oleh ahli sejarah). Dengan demikian inti permasalahannya 
adalah bahwa Ken Dedes merupakan tokoh utama atau gambaran dari seorang ratu atau parameswari dari pendiri dinasti. Sebutan Nareswari bagi Ken Dedes sebenarnya lebih menunjuk kepada keberadaan Ken Dedes sebagai seorang wanita yang menyandang predikat parameswari (dewi tertinggi/wanita utama) dari Sri Rajasa Amurwabhumi di Singasari.

Berangkat dari awal pembahasan di atas, terdapat beberapa indikasi yang memberikan peluang untuk menempatkan sosok Ken Dedes dalam perwujudan sebagai dewi Prajñaparamita, yaitu:

\section{a. Religi yang dianutnya}

Ken Dedes adalah seorang putri tunggal dari pendeta agama Budha Mahayana, yaitu Mpu Purwa, yang memiliki pertapaan di setra penduduk Panawijen. Indikator 'Setra' menunjuk kepada suatu tempat sebagai lapangan mayat (Mardiwarsito, 1986:521; Zoetmulder, 2004:524). Sedangkan tempat tersebut merupakan salah satu tempat dimana terdapat 'yantra' bagi sekte Tantra guna sarana pelaksanaan ritualnya, yaitu mayat. Setra atau lapangan mayat (pekuburan) sebagai tempat mengolah yoga, disebut-sebut dalam naskah Sang Hyang Kamahayanikan bersama-sama dengan tempat-tempat mélakukan yoga yang lain, yaitu sebagai berikut: 'Yan molaha ring wukir, gihã, sãgaratîra, kunang kuti, wihãra, gramanaruka patapãn, kunang kita ring k $^{\circ}$ etra haraòan ....' (Sumonggokarso, 1988:47). Dalam Sutasoma nyanyian 125 bait 10 (Santoso, 1975:523), diterangkan berkenaan dengan cara-cara penggunaan yantra 'mayat manusia', yaitu sebagai berikut: "Akeweh bhẩwa nireki dudwang apayụng sirar atêhêr ayoga dhãraka. Milyang rah mahamêng titisnya tumibeng hulu nira-ya tumis têkeng jaja. Antra nyãwiletan lalêr wilis aneka ri muka mangurambat ing mata. Ndãtan simpang ike manah nira sumãdhya ri turuna bhapãra Hairuka".

Dapat diduga bahwa agama Budha Mahayana yang dianut oleh Mpu Purwa adalah Mahayana sekte Tantra yang disebut Vajrayana (Kats dalam Rita Istari, 2002:40), salah satu sekte yang terkenal pada waktu itu di Jawa dan Sumatera. Dimana dalam ajarannya diutamakan pemujaan terhadap segala sesuatu yang bersifat gaib serta unsur wanita atau dewi. Sedangkan unsur wanita dalam agama Hindu maupun Budha dikenal dengan istilah 
Sakti. Namun perlu digarisbawahi bahwa ajaran Tantra tidak selalu mencerminkan praktek-praktek negatif. Dalam pengertiannya, ajaran ini dibedakan menjadi dua ajaran pokok, yaitu: aliran kiri (nivretti) dan aliran kanan (pravretti) (Rita Istari, 2002:42).

Sehubungan dengan pengertian di atas, kiranya bukanlah sesuatu yang dicari-cari apabila Ken Dedes sebagai putri dari pendeta Budha Mahayana sekte Vajrayana, tentunya juga mempelajari ajaran ayahnya (kalawan ta anakingsun marajaken karma amamadangi). Dari fakta ini patutlah dipahami mengapa ia diarcakan sebagai dewi Prajñaparamita.

\section{b. Gelar yang disandangnya}

Kata 'Ken' merupakan gelar yang diberikan oleh pengarang Pararaton untuk menunjukkan bahwa tokoh yang bersangkutan memiliki derajat yang tinggi. Zoetmulcier (2004:495) dalam keterangannya menyatakan bahwa 'Ken' merupakan partikel di depan kata benda (sebagai kategori atau nama diri) yang menunjukkan bahwa orang yang bersangkutan adalah orang berpangkat. Ken diduga merupakan alih bunyi dari kata 'Rakryan' dalam bahasa Jawa kuno. Dengan demikian pengarang Pararaton menulis partikel 'Ken' di depan nama Ndok, Angrok, dan Dedes merupakan suatu penghormatan guna menunjuk bahwa mereka adalah orang-orang berderajad luhur bukan keturunan raja, tetapi sebagai keluarga pendiri dinasti Rajasa di Singasari. Suatu kenyataan bahwa keturunan dari pendiri dinasti ini dalam Pararaton tidak ada yang disebut 'Ken'.

\section{c. Karma yang diajarkan oleh mpu Purwa kepadanya}

Pararaton memberikan keterangan bahwa Ken Dedes oleh ayahnya diberi bekal ajaran karma amamadangi (marajaken karma amamadangi). Marajaken berasal dariakar kata' 'Raja' yang berarti menyala atau bersinar (Zoetmulder, 2004:904), sedangkan 'Karma' berarti tindakan, pekerjaan, sebarang perbuatan baik atau buruk yang mengakibatkan hasil yang tak dapat dielakkan pada masa yang akan datang (Zoetmulder, 2004:464). Marajaken karma amamadangi dapat diartikan sebagai ' yang memiliki cahaya (ilmu) tentang perbuatan baik yang dapat menerangi hidup'. 
Cahaya ilmu tentang karma yang dapat menerangi hidup yang diajarkan Mpu Purwa kepada Ken Dedes tentulah sebuah ajaran karma yang dalam agama Budha Mahayana dibagi menjadi 3 bagian, yaitu:

1). Mano karma perbuatan yang dilakukan oleh pikiran

2). Vacci karma, perbuatan yang dilakukan oleh kata-kata

3). Kaya karma, perbuatan yang dilakukan oleh badan jasmani

Dari ketiga karma tersebut, pengertian karma secara luas adalah "Semua perbuatan, baik yang dilakukan oleh pikiran, perkataan, maupun jasmani yang terjadi karena kehendak (cetana)" (Diputera, 1984:13).

Bagaimana cara untuk dapat melakukan karma yang baik (kusala karma) sehingga jalan hidup dapatterterangi? Menurut ajaran sang Budha, terdapat sepuluh macam jalan untuk melaksanakan perbuatan baik yang disebut Dasa Purnnakirya atau Sepuluh jalan dari perbuatan baik (Diputera, 1984:24), yaitu:
1) Dana
2) Sila
3) Bhavana
4) Apacayana
5) Beyyavacca

6) Prattidana

7) Prattanumodana

8) Dharmasavana : mempelajari

8) Dharmasavana

9) Dharmadesana yang baik gemar menolong orang dan murah hati melakukan perbuatan, ucapan, dan matapencaharian yang benar

mengheningkan cipta untuk membersihkan kekotoran pikiran yang baik

rendah hati dan menghormati orang yang patut dihormati, tidak sombong

memberikan jasa-jasa baik kepada orang lain untuk dapat melakukan perbuatan-perbuatan

suka membagi kebahagiaan, kegembiraan kepada orang lain, tidak kikir, dan tidak mementingkan diri sendiri

merasa turut bahagia dan gembira melihat orang lain bahagia, dan tidak ada samasekali perasaan iri hati

mempelajari dharma dan sering mendengarkan khotbah, ceramah dharma menyebarkan dharma dan memberikan pelajaran tentang dharma 
10). Dirtihiyukarma : pandangan hidup yang benar, daripada mendengarkan khotbah dan melaksanakan semedi.

Disamping jalan karma yang baik tersebut, terdapat ajaran delapan jalan kebenaran yang wajib ditempuh oleh umat. Delapan jalan kebenaran itu merupakan sarana untuk menghilangkan penderitaan (Samsara) yang tumimbal dalam mati lahir. Adapun delapan jalan kebenaran tersebut tercakup dalam tiga tingkatan, yaitu:
1) Prajña
: dihubungkan dengan keadaan akal budi
2) Sila
: dihubungkan dengan tingkah laku
3) Samadhi
: dihubungkan dengan proses konsentrasi batin

Dengan bersamadi menjernihkan akal pikiran, maka akan dapat melemahkan kekuatan keinginan nafsu. Setelah itu baru melakukan Sila, yaitu perbuatan yang dapat mengendalikan nafsu, sehingga tercapai suatu 'Susila'. Apabila Samadi dan Sila dapat dilakukan dengan baik dan sempurna, maka yang akan tercapai adalah Prajña (kebijaksanaan). Prajña berguna untuk melenyapkan nafsu yang merupakan sebab utama dari penderitaan (Samsara). Dengan demikian antara Prajña, Sila, dan Samadhi memang merupakan satu kesatuan yang tidak terputus. Kewajiban perbuatan semacam ini memang sulit dilakukan oleh seorang umat biasa, oleh karena itu haruslah ia seorang umat yang memang benar-benar meninggalkan keduniawiannya (dalam hal ini para bhiksu maupun bhiksuni).

Sebagai anak seorang pendeta Budha Mahayana yang telah mendapatkan ajaran karma dari ayahnya, serta perjalanan hidupnya sebagai parameswari pendiri Dinasti Rajasa di Singasari. Sangat mungkin di masa akhir hidupnya ia mengundurkan diri dan menjadi bhiksuni. Sebagaimana tradisi yang dilakukan oleh kebanyakan para pembesar kerajaan diusianya yang telah lanjut. Dalam kedudukannya sebagai bhiksuni itulah ia lebih mengkonsentrasikan diri guna mengolah karma yang lebih baik, sehingga tahapan-tahapan dalam memperoleh Kusalakarma dapat dicapainya melalui Samadhi, Sila, dan Prajña. 


\section{d. Pamor kedudukannya sebagai permaisuri pendiri dinasti}

Segala cahaya dan sinar yang dilukiskan pada diri Ken Dedes merupakan suatu gambaran atau lambang untuk menunjukkan bahwa ia adalah sosok wanita utama (parameswari) yang merupakan sumber atau benih asalusul raja-raja Singasari dan Majapahit. Sebagai tokoh wanita utama, ketika ia meninggal sudah selayaknya ia dipatungkan sesuai dengan tabiat dan karmanya ketika ia masih hidup. Sebagaimana Ken Angrok (Rajasa Amurwabhumi), ia mengaku sebagai titisan bhatara Guru (Siwa), maka ketika meninggal dimuliakan dalam wujud Siwa. la dimuliakan di dua tempat. Tempat pendharmaan pertama adalah Kagenengan sebagai Siwa, dan tempat pendharmaan kedua adalah di Usana sebagai Budha. Hal ini menunjukkan bahwa Rajasa Amurwabhumi menganut sistem kepercayaan ganda (ajaran Siwa Budha).

Adapun Ken Dedes, di masa akhir hidupnya, matinya, serta tempat pendharmaannya samasekali tidak disinggung baik dalam Pararaton maupun Negarakertagama. Sungguhpun demikian sebagai seorang permaisuri pendiri dinasti, jelas ia dimuliakan, hanya tempatnya yang tidak diketahui. Dari daftar tempat pendharmaan yang dicatat oleh Prapanca dalam Negarakertagama pupuh 73 menyebutkan bahwa dari candi-candi pendharmaan utama yang disebut pertama adalah Kagenengan, kedua adalah Tumapel, ketiga adalah Kidal, keempat Jajagu, dan seterusnya.

Kagenengan disebut pertama jelas merupakan tempat pendharmaan Rajasa Amurwabhumi sebagai raja pendiri dinasti. Dan itu juga diakui oleh Prapanca sebagai penulis Negarakertagama. Kedua adalah Tumapel, ketiga adalah Kidal sebagai tempat pendharmaan Anusapati, keempat adalah Jajagu sebagai tempat pendharmaan Wisnuwardhana. Dari cara menyebut tempat-tempat di atas secara kronologis, jelas menunjuk secara berurutan raja-raja yang memerintah di Singasari.

Jika demikian halnya, tempat pendharmaan siapakah Tumapel? Apakah Tumapel sama dengan Usana? Jika Tumapel sama dengan Usana, maka Tumapel adalah tempat pendharmaan Rajasa Amurwabhumi sebagai Budha. Dan jika demikian, maka sudah sewajarnya apabila permaisurinya juga dibuatkan tempat pendharmaannya di Usana sebagai sakti sang Budha 
yaitu Prajñaparamita. Tetapi apabila Usana tidak sama dengan Tumapel, maka pendharmaan Tumapel adalah tempat satu-satunya candi untuk pendharmaan Ken Dedes sebagai Prajñaparamita. Dan dugaan tempat itu adalah candi putri atau candi Wayang sekarang. Sebagai catatan bahwa dijaman Singasari akhir dan jaman Majapahit, ternyata Tumapel digunakan lagi sebagai candi pendharmaan. Terbukti secara arkeologis di tempat tersebut ditemukan sekitar 4 reruntuhan candi.

Sebagai seorang parameswari yang taat pada ajaran Budha, sebagai istri dari seorang penganut kepercayaan ganda (Siwa Budha), sangat sesuai apabila Ken Dedes dipatungkan dalam bentuk Prajñaparamita yang merupakan dewi dalam pantheon Mahayana Tantra atau Vajrayana. Dalam susunan pantheon madshab ini diketahui bahwa di alam Nirguna, sang Budha tertinggi mempunyai imbangan sakti yaitu dewi Prajñaparamita (Pott dalam Pitono, t.t:14). Dengan demikian Pararelisasi antara keduanya bahwa Rajasa Amurwabhumi pendiri dinasti, di Usana diarcakan sebagai Budha, memiliki imbangan sakti yaitu permaisuri Ken Dedes yang diarcakan sebagai Prajñaparamita.

\section{Kesimpulan}

Prajñaparamita merupakan sosok dewi dalam pantheon Budha Mahayana sekte Tantrayana yang disebut juga Vajrayana. Di dalam susunan pantheon madshab ini, ia merupakan sakti (esensi kekuatan) dari sang Budha tertinggi yang berkedudukan di alam Nirguna (alam sunyata). Sebagai sifat kebijaksanan tertinggi/sempurna dari sang Budha yang bersifat maskulin, maka ia dipersonifikasikan dalam bentuk feminin (seorang dewi). Dalam pengarcaan ia ditandai oleh laksana yang khas, yaitu pustaka di atas kelopak bunga teratai merah (padma), serta mudranya yang Dharmacakra.

Arca Dewi Prajñaparamita yang ditemukan di candi Putri atau candi Wayang komplek percandian Singosari, adalah arca produk jaman Singasari (abad ke-13). Hal itu dapat dibuktikan dengan ciri kesenian Singasari yang khas, yaitu tumbuhan teratai yang keluar dari umbinya. Juga persamaan gaya dengan arca Siwa dari candi Kidal. Dengan demikian arca tersebut haruslah menggambarkan tokoh bangsawan putri dari kerajaan Singasari. 
Tokoh bangsawan putri yang legendaris di kerajaan Singasari adalah Ken Dedes. Sebagai anak seorang pendeta Budha Mahayana Tantra, tentunya ia adalah penganut yang saleh (dalam Pararaton diisyaratkan dengan katakata Mpu Purwa:'anakingsun marajaken karma amamadangi'), sebagaimana ajaran yang diterima dari ayahnya. Dalam perjalanan hidupnya ia menjadi seorang parameswari (dewi tertinggi/wanita yang utama)dari pendiri dinasti. Di dalam Pararaton diisyaratkan sebagai seorang wanita yang bersinar rahasia kewanitaanya (mengandung 'yoni'), seorang nareswari.

Di pihak Rajasa Amurwabhumi sebagai raja pendiri dinasti, dalam keagamaannya ia menganut kepercayaan ganda (Siwa Budha). Sistem kepercayaan yang berbau tantris ini dalam ritualnya lebih mengutamakan unsur sakti (feminin). Dengan demikian wajarlah apabila ketika wafatnya, ia didharmakan di dua tempat. Di Kagenengan sebagai Siwa, dan di Usana sebagai Budha. Ken Dedes sebagai parameswari dari pendiri dinasti, ketika wafatnya didharmakan dengan dibuatkan patungnya dalam wujud Dewi Prajñaparamita, yaitu sakti dari sang Budha tertinggi. Ini melambangkan perpaduan dirinya sebagai seorang sakti (feminin) dari pendiri dinasti (Rajasa Amurwabhumi) yang ketika wafatnya diarcakan sebagai Budha (maskulin). Disamping juga sebagai gambaran untuk menunjukkan sifatsifat pengetahuan agama yang telah dirasuknya dimasa hidupnya.

Dari pembahasan di atas dapat dikatakan bahwa arca Dewi Prajñaparamita yang ditemukan di candi Putri atau candi Wayang komplek percandian Singosari adalah perwujudan dari Ken Dedes, parameswari dari Sri Rajasa Amurwabhumi, pendiri kerajaan Singasari. 


\section{KEPUSTAKAAN}

Bernet Kempers, AJ. 1959. Ancient Indonesian Art. Amsterdam: CPJ. Van Der Peet.

Blom, Yessy. 1939, The Antiquites of Singasari. Terjemahan Mudjadi dan Agus Salim 1976. Surabaya:FKIS-IKIP

Diputera, Oka. 1984. Citra Agama Budha dalam Filsafah Pancasila. Jakarta:

Proyek Bimbingan dan Dakwah Agama Hindu dan Budha.

Geldern, Robert Heine. 1982. Konsepsi Tentang Negara \& Kedudukan Raja-di Asia Tenggara. Terj. Deliar Noer. Jakarta: CV. Rajawali.

Mardiwarsito, L. 1986. Kamus Jawa Kunc-Indonesia. Ende-Flores: Nusa Indah

Nawawi, Hadari. 1985. Metode Penelitian Bidang Sosial. Yogyakarta: Gajah Mada University Press.

Noto Susanto, Nugroho. 1978. Masalah Penelitian Sejarah Kontemporer: Suatu Pengalaman. Jakarta: Yayasan Idayu.

Padmapuspita, Ki .J.1966. Pararaton. Yogyakarta: Taman Siswa.

Pitono, R. tanpa tahun. Pengaruh Tantrayana pada Kebudayaan Kuno di Indonesia. Malang: IKIP

Istari, R. (2002). Pelaksanaan Upacara Ritual Dalam Tantrayana. Berkala Arkeologi, 22(1), 40-48. https://doi.org/10.30883/jba.v22i1.848

Santoso, Suwito. 1975. Sutasoma A Study in Javanese Vajrayana. New Delhi: International Academy of Indian Culture.

Slametmulyana. 1979. Nagarakertagama dan Tafsir Sejarahnya. Jakarta:Bhratara Karya Aksara

Stutteirheim, WF. 1939. Een Bijzettingsbeeld van Koning Rajasa? Tijdschrift voor Indische Taal, Land, en Volkenkunde (hal.85-104) Deel LXXIX. KBG

Sumonggokarso, Dharmakirty. 1988. Sang Hyang Kamahayanikan. Jakarta: Lovina Indah

Suwardono. 2005. Mutiara Budaya Polowijen. Malang: Dinas Parinkom Pemerintah Kota Malang

Zoetmulder, PJ. 2004. Kamus Jawa Kuno Indonesia. Jakarta: Gramedia. 